\title{
Effect of Integrated Soil and Water Conservation Practices on Vegetation Cover Change and Soil Loss Reduction in Southern Ethiopia
}

\author{
Dessale Wasie $^{1}$, Fantaw Yimer ${ }^{2}$, Shiferaw Alem ${ }^{3}$ \\ ${ }^{1}$ Department of Soil and Water Resource Management, College of Agriculture, Woldia University, Mersa, Ethiopia \\ ${ }^{2}$ School of Natural Resources and Environmental Studies, Wondo Genet College of Forestry and Natural Resources, Hawassa University, \\ Shashemanne, Ethiopia \\ ${ }^{3}$ Department of Forest Botany, Dendrology and Geobiocoenology, Mendel University in Brno, Hawassa, Ethiopia
}

Email address:

dessewasie@gmail.com (D. Wasie), fantawyimer2003@gmail.com (F. Yimer), shiferawalem@gmail.com (S. Alem)

\section{To cite this article:}

Dessale Wasie, Fantaw Yimer, Shiferaw Alem. Effect of Integrated Soil and Water Conservation Practices on Vegetation Cover Change and Soil Loss Reduction in Southern Ethiopia. American Journal of Environmental Protection. Vol. 9, No. 3, 2020, pp. 44-50.

doi: 10.11648/j.ajep.20200903.12

Received: January 15, 2020; Accepted: March 4, 2020; Published: June 3, 2020

\begin{abstract}
Soil erosion is a major challenge in sustaining agricultural production. Area closure with tree planting and physical conservation measures, implemented by various land rehabilitation programs is one of the best options to address the soil erosion problem. This study was conducted to assess the effect of integrated soil and water conservation (SWC) practices on woody vegetation rehabilitation and soil erosion reduction in Hawassa Zuriya Woreda, Southern Ethiopia. Vegetation cover type classification and delineation were completed for each land management category (closure area with SWC, closure area without SWC and open grazing area) in the field. RUSLE model integrated with a GIS environment was used to estimate the annual soil losses. Results showed that SWC practices were increased forest, shrub and grass coverage, and reduced bare land surface coverage. The average $C(p=0.02)$ and $P$ values $(p=0.04)$, and annual soil erosion rate were significantly lower in closure with SWC ( $p=0.0001)$ compared to the value without SWC and open grazing land. Thus, the average annual soil erosion rate was reduced below a tolerable $(<1 \mathrm{t} / \mathrm{ha} / \mathrm{yr}$.) level by SWC practices. The overall results confirmed that integrated soil and water conservation practices reduced soil erosion rates and improved woody species diversity. Therefore, area closure integrated with SWC practices is the best option to improve the biophysical condition of degraded lands.
\end{abstract}

Keywords: Area Closure, Grazing Land, Soil Erosion, Species Diversity, Vegetation Cover

\section{Introduction}

Land degradation is a serious global environmental problem confronting mankind over the year [1]. Almost all inhabited lands in Sub-Sahara Africa (SSA) are prone to land degradation [2]. Similarly, natural resource and land degradation in Ethiopia is exceedingly high [3]. Land use conversion mainly, deforestation due to the expansion of agriculture towards the steeper slopes in response to the demand of increased population, aggravates land degradation in Ethiopia [4]. Soil erosion by water is a major agent of land degradation in Ethiopia and it has significant impacts on ecosystem services, crop production, downstream flooding, and reservoir sedimentation and economic costs [5].
The amount of yield reduction following the loss of topsoil in each year has been increasing considerably [6]. This makes the issue of soil conservation measures as a vital concern for Ethiopia to achieve sustainable development of its agricultural sector and the economy at large [7]. Among the various techniques of rehabilitation used, the predominant one is area closures, through tree-planting integrated with physical conservation measures [8]. Thus, soil conservation measures are a necessary part of the system for combating erosion during critical times of the year and showed a certain effect [9]. It has a positive contribution to the reduction of soil erosion, conservation of soil moisture and restoration of vegetation cover and diversity [10].

Ethiopian highlands in general and Hawassa Zuriya 
Woreda, in particular, are susceptible to land degradation due to their rugged topographic features and anthropogenic impacts such as deforestation, uncontrolled grazing and agricultural practices. This degradation has resulted in the loss of nutrient-rich topsoil and thereby reducing the crop yield [8]. At the same time, a rapid runoff would reduce recharge of groundwater, siltation and rapid decrement of the storage capacity of Lake Hawassa. Consequently, the risk of soil erosion has persisted and will continue as a serious threat to farmers' 'livelihood and economic development in the area [11].

To solve these problems a project known as "Degraded land rehabilitation as a base for sustainable management of natural resources in Hawassa Zuriya Woreda, SNNPR" was implemented by Mendel University in Brno. The project aim was to improve the ecological stability of the area through enhancement of local capacities, by the introduction of complex erosion control measures and implementation of landscape management plan. Since the launching of the project, different researchers have assessed the impact of the intervention measure in the area. For example [12] have compared and evaluated different community mobilization approaches for rehabilitating degraded lands. Even though the project is going to be terminated this year, there has not been any research conducted to assess the effect of area closure integrated with SWC practices on vegetation restoration and soil loss reduction. Therefore, the objective of this study was to assess the effect of area closure integrated with soil and water conservation practices on vegetation cover change and soil loss reduction in Hawassa Zuriya Woreda, southern Ethiopia.

\section{Materials and Methods}

\subsection{Description of the Study Area}

The study was conducted in Hawassa Zuriya Woreda, Sidamo Zone of Southern Nation, Nationalities and Peoples Regional State (SNNPRS), Southern Ethiopia. Geographically, it is located between $7^{\circ} 2^{\prime} 30^{\prime \prime}$ and $7^{\circ} 3^{\prime} 30^{\prime \prime} \mathrm{N}$ latitude; and $38^{\circ}$ $17^{\prime} 0^{\prime \prime}$ and $38^{\circ} 19^{\prime} 0^{\prime \prime}$ E longitude (Figure 1).

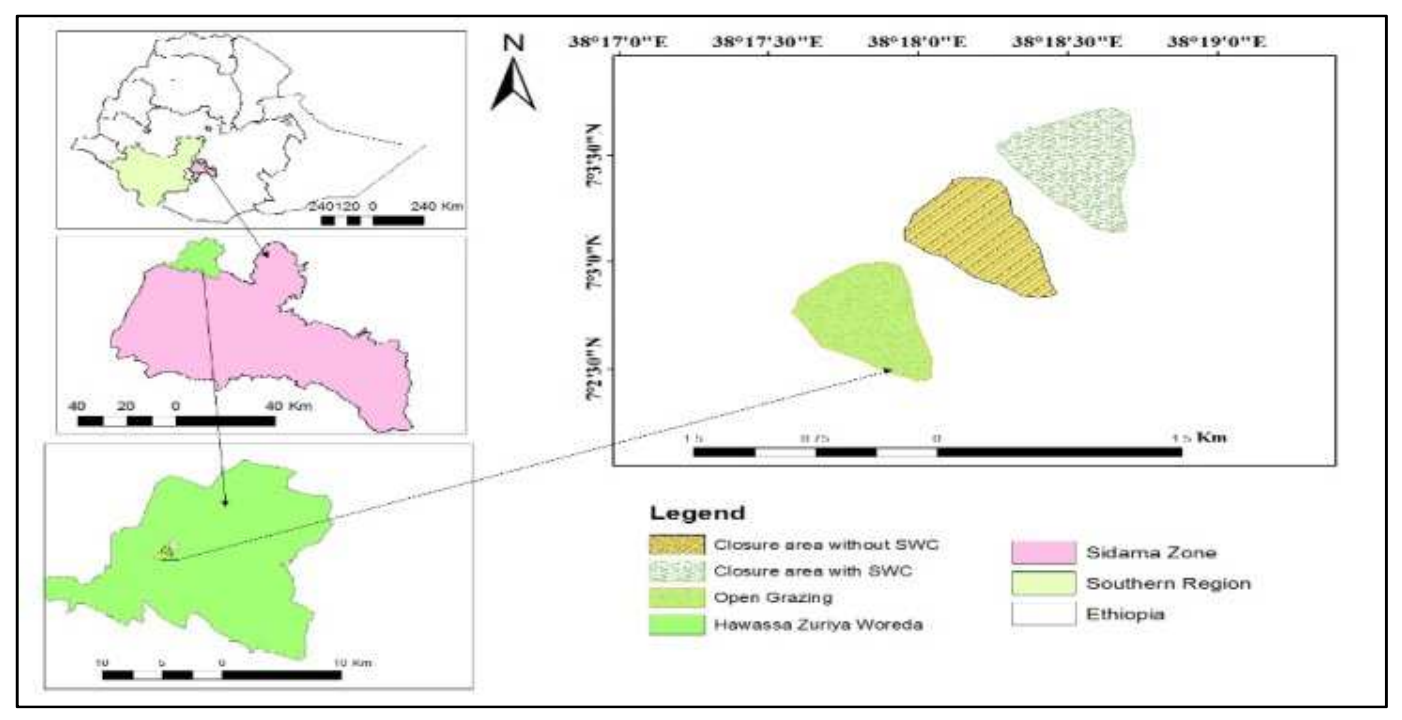

Figure 1. Study Site.

In terms of an agro-climatic zone, the study area falls within the dry woina-dega (mid-altitude) category [11]. The average annual precipitation (1987 to 2016) in Hawassa station, near the study area, is about $953 \mathrm{~mm}$. The annual rainfall ranges between 950 to $1400 \mathrm{~mm}$. The mean monthly rainfall is above $100 \mathrm{~mm}$ from April to September with May showing the highest mean monthly rainfall at $122 \mathrm{~mm}$. The months with the lowest rainfall are November, December, and January. The mean annual temperature ranges from 23 to $27^{\circ} \mathrm{C}$ and the daily maximum ranges from 19 to $21^{\circ} \mathrm{C}$ and the daily minimum ranges from 13 to $17^{\circ} \mathrm{C}$ [11].

The elevation in the study area ranges from $1,900 \mathrm{~m}$ at the bottom to almost 2,030 $\mathrm{m}$ above sea level in the upper ridge. The mean altitude of the study area is $1,965 \mathrm{~m}$ above sea level. The major landform in the study site includes flat to gently sloping (3.1\%), sloping to strongly sloping (49.5\%), moderately steep $(41.65 \%)$ and steep to very steep $(5.75 \%)$.
Eutric Cambisol is the dominant soil type in the study area. The soil is moderately deep to very deep, and fine to medium textured. Eutric Cambisol is among the most productive soils in Ethiopia and it slightly eroded by the rill, sheet, and gully erosion. It also developed on level plain landform and mountainous landform in all slope classes [8, 11].

The major land use types include grassland with shrubs, grassland for grazing, bare surface with degraded grass cover and limited vegetation along drainage lines. The major woody species dominating the area include acacia species, Albiziagummifera, Albiziaschimperiana, Balanitesaegyptiaca, Croton macrostachyus, Ficussycomorus, Maytenusundata, Rhusnatalensis Acacia tortilis, Acacia bussei, and Dodonaea angustifolia are common [11,13]. The major physical soil and water conservation measures established in the project area are trenches with improved pits and water harvesting ponds. The types of tree/shrub species planted were Acacia saligna, 
Casurina equistifolia, Grevillea robusta, Moringa stenopetalla, Acacia senegal, Acacia abysinica, Acacia sayel, Dodonaea angustifolia, and Sesbania species [14].

\subsection{Reconnaissance Survey and Site Selection}

A reconnaissance survey of the study area was undertaken in the first week of November 2017. During the field survey, the general overview of the area was obtained to identify the study site containing both biophysically conserved and nonconserved adjacent areas having similar histories. Therefore, for the purpose of this research, parts of the area closure and the adjacent open grazing land which have the same topographic, soil and parent material, climatic characteristics, and history but with different management intervention were selected. Then, the selected site was categorized into three management categories (closure area with SWC, closure area without SWC and open grazing land).

The open grazing land was included for the purpose of comparison as a control. It is an open area used for grazing purpose and not any management practices applied in the area. While, closure area with SWC is an area of land where, the interference of animals is avoided and various SWC practices like a trench, check dams, pits, ditches, gabions and ponds and biological SWC like enrichment planting were implemented. But, closure without SWC is simply excluded only animal and human interferences without applying any SWC practices.

\subsection{Land Cover Type Classification}

The woodland, shrub, grass and bare land surface cover types in the three land use types were identified, classified and delineated in the field by using GPS. For each cover classes, the corresponding XY points were recorded. The analysis was based on XY coordinates recorded by using GPS in the field. Arc GIS10.1 software was used in the classification processing, vectorization, area calculation, and thematic map preparation. The GPS points recorded from each vegetation cover types at each land use types were downloaded from GPS to a computer by using map sources and saved in CSV (comma separated value) format. Each file saved in CSV format were imported into Arc GIS10.1 and create point features, for each vegetation cover type classes. From point features, polygon features were created by Xtool pro analysis extension tool. The classified vegetation cover types were overlay on each land management category boundary. Finally, maps were generated to indicate the variability of vegetation cover type classes in the three land management types and to view the statistics result. Then, converted into raster form and reprojected to the projection called Adindan UTM Zone $37 \mathrm{~N}$ which was the same projection used for other datasets.

\subsection{Soil Sampling and Laboratory Analysis}

A total of 12 transect lines (4 transect $\times 3$ land management units) and 60 sampling quadrants (4 transect $\times 3$ land management units $\times 5$ sample plots) each with a size of 20 $\mathrm{m} \times 20 \mathrm{~m}$ were established for soil sampling. Soil samples were collected at a depth of $0-20 \mathrm{~cm}$ by the auger from the four corners and center of each sample plot. The collected samples from the three sites were mixed thoroughly and separately to form 60 composite soil samples (3 land use $\times 4$ transect $\times 5$ replication). Soil samples taken at depth of 0-20 cm were used as being more sustainable for estimating soil erodibility value assessing sheet and rill erosion risk [9]. The samples were labeled and moved to the soil laboratory for analysis purpose. The samples were air dried at room temperature and passed through a $2 \mathrm{~mm}$ soil sieve. The samples were analyzed at Wondo Genet College of Forestry and Natural Resource Soil laboratory. Soil organic matter was determined by following the Walkley and Black method [15]. The soil textural fraction was determined by using the hydrometric method as used by [16]. The soil organic matter and texture were used to compute the soil erodibility $(\mathrm{K})$ factor.

\subsection{Soil Erosion Estimation}

RUSLE model integrated with GIS environment was used for predicting the average annual soil loss. This method is preferred to others because it is commonly applied with reliable accuracy at watershed scales when detailed input data are less available [9]. First, individual GIS files were built for each RUSLE factor and combined on a cell by cellgrid modeling procedure, to predict soil loss per hectare per year in each site.

Rainfall erosivity is estimated using the EI30 measurement. However, the data of rainfall kinetic energy and intensity are not available in developing countries like Ethiopia. Therefore, the erosivity R factor of the RUSLE was estimated by using metrological station's rain fall data at Hawassa, Wondo Genet, Shashemene, Alaba, Hosana and Haisawita, which are evenly distributed and located around the study area. The average annual rainfall values of these stations were first imported to ArcGIS as point vector data. Then, interpolated using IDW (Inverse Distance weighted) Spatial Analyst Tool to generate continuous rainfall data for each grid cell of combination set of sample points. Thus, $\mathrm{R}$ factor was calculated based on the equation developed by [17], performed an adaptation of RUSLE to the EthiopianEritrean Highland conditions using two to five years of research data from six SCRP stations and was found regression equation to estimates R-value for Ethiopia from annual total rainfall.

$$
\mathrm{R}=0.562 \times \mathrm{P}-8.12
$$

Where $\mathrm{R}$ is the rainfall erosivity factor $(\mathrm{J} \cdot \mathrm{m}-1 \cdot \mathrm{hr}-1$ year- 1$)$ and $\mathrm{P}$ is the mean annual rainfall $(\mathrm{mm})$.

According to [18], soil erodibility factor is calculated by using soil organic matter, particle size parameter, soil structure and permeability. When the available or collected data set lacks any of these soil properties alternative methods can be adapted. In this study, the soil erodibility factor was estimated by using organic matter and soil texture (Table 1). Finally, the soil erodibility point data was converted into a 
rasterized surface through IDW interpolation technique.

Table 1. Determination of K-factor from soil organic matter and texture analysis [3].

\begin{tabular}{llll}
\hline \multirow{2}{*}{$\begin{array}{l}\text { Basic textural } \\
\text { class }\end{array}$} & \multicolumn{3}{l}{ Organic matter content } \\
\cline { 2 - 4 } & Average K Factor & $<\mathbf{2 \%}$ & $>\mathbf{2 \%}$ \\
\hline Sandy loam & 0.13 & 0.14 & 0.12 \\
Sandy clay loam & 0.2 & 0.2 & 0.2 \\
Clay loam & 0.305 & 0.33 & 0.28 \\
Loam & 0.3 & 0.34 & 0.26 \\
Clay & 0.225 & 0.24 & 0.21 \\
\hline
\end{tabular}

In erosion prediction both slope length ' $\mathrm{L}$ ' and slope gradient ' $\mathrm{S}$ ' can be evaluated together and substantially affects sheet and rill erosion estimated by RUSLE [18]. Digital Elevation Model (DEM) and GIS techniques were used to obtain both slope gradient (S) and slope length (L). A $30 \mathrm{~m}$ resolution DEM was first pre-processed and clipped by appropriate size of the study area to drive the LS factor. Then, the values of flow length and slope gradient were derived from DEM. Slope (\%) was directly derived from the DEM. However, flow length was derived from the DEM after conducting Fill and Flow Direction processes. Finally, the LS factor map was generated using the following equation, used by [9], in GIS spatial analysis raster calculator function.

$$
\mathrm{LS}=\left(\lambda^{0.5} / 22.1\right) \times(\mathrm{S} / 9)^{1.3}
$$

Where $\lambda$ signifies the flow length and $\mathrm{S}$ is slope in percent.

The $\mathrm{C}$ factor represents the ratio of soil loss under a given crop to that of the bare soil [19]. In this study, the vegetation cover type map was used for the estimation of $\mathrm{C}$-value. The $\mathrm{C}$ factor value was estimated from each vegetation cover type classes based on the cover value proposed by [17] for Ethiopian condition (Table 2). Then, using reclassification and vector to raster conversion the vegetation cover type map was converted to $\mathrm{C}$ factor map.

Table 2. LULC Categories and the corresponding C-value [17].

\begin{tabular}{lllll}
\hline LULC & Forest & shrub & Grass land & Bare land \\
\hline C value & 0.01 & 0.014 & 0.05 & 0.6 \\
\hline
\end{tabular}

The $\mathrm{P}$ factor value was estimated based on the value suggested by [20] that considered P-values for different conditions of conservation measure on arable and non-arable land. The type and quality of SWC practices found in the study area were identified and recorded at the field during observation (appendix). Then, the P-values were estimated by using $\mathrm{P}$ factor value proposed by [20] for different conditions of conservation measure on non-arable land (Table 3). Finally, the P factor point data was converted into a rasterized surface through IDW interpolation technique.

Table 3. P factor Value under different condition [20].

\begin{tabular}{lll}
\hline $\begin{array}{l}\text { SWC } \\
\text { condition }\end{array}$ & Description & $\begin{array}{l}\text { P factor } \\
\text { value }\end{array}$ \\
\hline None & There is no SWC & 1 \\
Remains & There is SWC but not maintained & 0.8 \\
Poor & $\begin{array}{l}\text { Poorly designed, constructed and maintained } \\
\text { Moderate }\end{array}$ & $\begin{array}{l}\text { Moderately designed, constructed and } \\
\text { maintained }\end{array}$ \\
Good & Well designed, constructed and maintained & 0.6 \\
\hline
\end{tabular}

Statistical analysis was investigated to test the impact of SWC measures on soil erosion reduction and different vegetation parameters using Statistical Package for Social Sciences (SPSS) version 16 following the procedure of oneway ANOVA. Mean comparisons were performed by using Tukey HSD test with $\mathrm{p}<0.05$.

\section{Results and Discussion}

\subsection{Effects on Vegetation Cover}

The vegetation cover type classification result showed that the closure area with SWC was characterized by woodland, shrub, and grassland. Shrub, Grass, and Bare land surface covers were identified in closure area without SWC. Similar vegetation cover type classes were also identified in open grazing area. The vegetation cover types were differed with land use types and changed with increasing the level of management (Table 4). As a result, the woodland cover type was only found in closure area with SWC.

Table 4. Land cover classes type area coverage (ha).

\begin{tabular}{|c|c|c|c|c|c|c|c|}
\hline \multirow{2}{*}{ No } & \multirow{2}{*}{ Cover type } & \multicolumn{2}{|c|}{ Closure area with SWC } & \multicolumn{2}{|c|}{ closure area without SWC } & \multicolumn{2}{|c|}{ Open grazing land } \\
\hline & & Area (ha) & $\%$ & Area (ha) & $\%$ & Area (ha) & $\%$ \\
\hline 1 & Woodland & 4.46 & 8.18 & - & - & - & - \\
\hline 2 & Shrub & 27.14 & 49.81 & 10.11 & 18.55 & 2.28 & 4.18 \\
\hline 3 & Grass & 22.89 & 42.01 & 37.67 & 69.12 & 30.72 & 56.36 \\
\hline 4 & Bare & - & - & 6.72 & 12.33 & 21.51 & 39.46 \\
\hline total & & 54.5 & 100 & 54.5 & 100 & 54.5 & 100 \\
\hline
\end{tabular}

Responses from field survey with local people suggest that woodland cover had increased due to the implementation of integrated SWC practices for the last ten years. Shrub coverage in closure area with SWC was higher than closure without SWC and open grazing land by $62 \%$ and $92 \%$, respectively. Similarly, closure area without SWC measure was higher than open grazing land by $77 \%$ (Table 4). In line with this result, [21] found that area of land covered by grass was changed to woodland and shrub coverage as a result of area closure integrated with various SWC practices. A study by [22] showed that the 27-yearold exclosures were dominated by large trees, and had $67 \%$ ground cover.

The Grass coverage in closure area without SWC was greater than closure area with SWC and open grazing by $28 \%$ and $13 \%$ respectively. Similarly, open grazing was higher than closure area with intervention measure by $17 \%$ (Table 4 ). A study by [22] showed that the 10 -year-old exclosures were 
largely dominated by grasses, where the average ground covers accounted about $60.5 \%$. The degraded land was first inhabited by opportunistic herbaceous vegetation and grasses, which were followed by relatively higher-layer vegetation (shrubs) succeeded by bushes and/or trees [4]. Similarly, [22] reported that the gradual replacement of lower layer by higher-layer vegetation with increasing age of the exclosures.

The bare land surface was not found in closure area with SWC. While, it was found in closure area without SWC and open grazing land. The area coverage of bare land surface in open grazing land was higher than closure area without SWC by $68 \%$ (Table 4 ). This is due to the increase in settlement in the upstream region of the watershed resulted in deforestation and overgrazing. The result of this study is coherent with the finding of [4, 21, 23]. Similarly, [22] reported that implementation of SWC practices increased the forest, shrub and grass coverage and reduced degraded area coverage in Wollo area, Ethiopia.

\subsection{Effects on Soil Erosion Reduction}

The average R, K, and LS factor value didn't show significant variation with land use types ( $\mathrm{p}>0.05$, Table 5). The average $\mathrm{R}$ factor values $\mathrm{J} \cdot \mathrm{mm} \cdot \mathrm{ha} 1 \cdot \mathrm{h}-1$ per year were almost similar among closure with SWC, closure without SWC and open grazing land (Table 5). This may be due to the effect of altitudinal range. Adjacent areas which are found in similar altitudinal range and slope position had similar rainfall because of similarity in decreasing temperature and increasing condensation with altitude on windward slopes [24]. Therefore, the effect of $\mathrm{R}$ factor on the overall annual erosion rate did not vary among the three land use types. Differences in $\mathrm{R}$ values represent differences in erosivity [25].

The mean soil erodibility ( $\mathrm{K}$ factor) value in closure with
SWC was lowered than open grazing land and closure without SWC (Table 5). Soils having high $\mathrm{K}$ factor value are the most erodible of all soils [19]. Therefore, the effect of soil condition under closure with SWC on the overall annual erosion rate was lower. This variation of soil erodibility factor among the land use types might be due to the effect of SWC practices on soil properties such as soil organic matter. According to [8], Soil under closure with SWC had higher soil organic matter than the adjacent closure without SWC and open grazing land, which is a result of the accumulation of organic matter through liter fall from plants. The accumulation of organic matter on the soil surface that may reduce the volume, velocity, and erosive capacity of surface run-off [27].

The average LS factor values were almost similar among closure with SWC, closure without SWC and open grazing land (Table 5). Although the mean LS value among land use types was similar, the higher LS value was observed in open grazing land followed by closure without SWC and closure with SWC. This variation may be due to the construction of SWC practices. According to [19], the constructions of SWC structures were reduced LS factor value by affecting slope length between structures, reduces the volume of runoff and thereby reduces soil loss.

The mean $\mathrm{C}$ and $\mathrm{P}$ factor value showed a significant variation with land use types $(p<0.05)$, higher in open grazing followed by closure area without SWC and with SWC (Table 5). As a result, the effects on the overall annual erosion rate are much significant. The low C-factor values have low contributions to the soil loss, where soil, climate, and topography are similar [19]. SWC practices and vegetation cover affects erosion mostly by modifying the flow pattern, grade or direction of surface runoff, and by reducing the runoff amount and rate [11].

Table 5. RUSLE Factors value (mean $\pm S D$ ).

\begin{tabular}{|c|c|c|c|c|c|c|}
\hline \multirow{2}{*}{ Land use types } & \multicolumn{6}{|c|}{ RUSLE Factors Value } \\
\hline & $\mathbf{R}$ & $\mathbf{K}$ & LS & $\mathbf{C}$ & $\mathbf{P}$ & $\mathbf{A}$ \\
\hline Closure with SWC & $533.6 \pm 0.09^{\mathrm{a}}$ & $0.13 \pm 0.001^{\mathrm{a}}$ & $1.11 \pm 0.09^{\mathrm{a}}$ & $0.03 \pm 0.01^{\mathrm{a}}$ & $0.4 \pm 0.01^{\mathrm{a}}$ & $0.92 \pm 0.09^{\mathrm{a}}$ \\
\hline Closure without SWC & $533.6 \pm 0.07^{\mathrm{a}}$ & $0.17 \pm 0.03^{\mathrm{a}}$ & $1.11 \pm 0.15^{\mathrm{a}}$ & $0.11 \pm 0.01^{\mathrm{b}}$ & $0.73 \pm 0.02^{\mathrm{b}}$ & $8.08 \pm 2.4^{b}$ \\
\hline Open grazing land & $533.6 \pm 0.07^{\mathrm{a}}$ & $0.21 \pm 0.05^{\mathrm{a}}$ & $1.11 \pm 0.16^{\mathrm{a}}$ & $0.27 \pm 0.02^{\mathrm{c}}$ & $0.8 \pm 0.09^{c}$ & $26.8 \pm 6.6^{\mathrm{c}}$ \\
\hline$P$ value & $>0.05$ & $>0.122$ & $>0.945$ & $<0.02$ & $<0.04$ & $<0.0001$ \\
\hline
\end{tabular}

The average estimated annual soil loss rate showed significant variation with land use types $(p<0.0001)$. It was lower under closure with SWC than the adjacent closure without SWC and open grazing land (Table 5). The results of this study fall within the ranges of the estimated soil loss for Ethiopia, which was ranging from 0 to 300 -ton $\mathrm{ha}^{-1} \mathrm{yr}^{-1}$ [17]. The soil loss amount observed in closure with SWC was below a tolerable level, compared with the closure without SWC. A study by [17] estimated that the soil loss tolerance level for the different agro-ecological zones of Ethiopia to be in the range of $1-16 \mathrm{t} / \mathrm{ha} / \mathrm{yr}$. The total annual soil loss was estimated to be $49.68,436$ and 1447 ton per year from an area of 54 ha in closure with SWC, closure area without SWC and open grazing land, respectively. Thus, closure with SWC and closure without SWC reduced annual soil loss by $96 \%$ and
$88 \%$, respectively, as compared with open grazing land.

The lower soil losses observed in closure with SWC was the effect of the integration of various SWC practices like bunds, trench, pit, and ponds with biological SWC practices. The fundamental roles of SWC structures are to reduce soil loss and its consequences. Practically, the loss that can be reduced by the structures is not only soil particles but also essential plant nutrients and applied fertilizers [27]. The dominant factors for the retarded soil loss in this area were the lower $\mathrm{C}$ factor and $\mathrm{P}$ factor values as a result of integrated SWC practices. A Study by [28] found that SWC practices were reduced soil loss by $88 \%$, compared to the land without structures. Similarly, in Debre Mewi, Ethiopia, SWC practices were reduced soil loss by $83.7 \%$ as compared with non-treated land [29]. A study in northern Ethiopia, Tigray 
by [20] found that SWC practices were effective in reducing soil loss by $68 \%$.

The dominant factors for the retarded soil loss in closure without SWC as compared with open grazing land were the lower $\mathrm{C}$ factor and $\mathrm{P}$ factor value resulted from area closure. A Study conducted in Tigray regional state, Ethiopia by [30] shows that 10 years old exclosure, reduced estimated soil erosion by $77 \%$ (from 52 to $12 \mathrm{Mg} \mathrm{ha}^{-1} \mathrm{y}^{-1}$ ). Similarly, [26] found that closure area with different land management practices has improved environmental conditions and through controlling soil erosion in degraded and open grazing lands. This can be because of exclosures has been restored the canopy of trees, shrubs and understory vegetation which can defense against soil erosion [31].

The higher value observed in open grazing land was due to the higher value of land use land cover types ( $\mathrm{C}$ factor) and $\mathrm{P}$ factor. These higher values are the result of the area without SWC practices and little vegetation cover. The greater the losses resulted from a larger value of these factors [25]. According to [9], a greater soil loss risk is observed in the land areas where the original forest cover has been degraded. Studies by [20, 32] showed that the higher soil loss amount was observed in open grazing land as compared with the adjacent area treated with SWC practices.

According to [3] reports about the soil erosion susceptibility and risk analysis results, areas of land with a poor plant cover showed high soil erosion susceptibility and risk. Similarly, in the open grazing land use type the higher coverage of bare land surface was possessing conditions for reducing erosion. The bare land surface was resulted from the forest land coverage changed to shrub and grass land due to the population pressure and expansion of agricultural practices [23].

\section{Conclusion}

Establishment of area closure integrated with soil and water conservation (SWC) practices was played a great role in vegetation rehabilitation and soil erosion reduction in the study area. The results revealed that SWC practices, particularly area closure with hillside traces and tree planting were helped to improve the vegetation cover. Similarly, woody species composition, richness, diversity, basal area, number of seedling and sapling were significantly improved by SWC practices. Area closure with various SWC had more potential to improve the regeneration status of woody species, where, the regeneration status was good in closure with SWC. This could be due to the effect of SWC practices on enhancing a number of seedling and sapling and improve DBH and Height class distribution of woody species.

The estimated annual soil loss significantly varied with land management units, where soil loss was below the tolerable level in closure with SWC. This could be attributed to the effect of SWC practices on vegetation cover $(\mathrm{C})$ and management practice $(\mathrm{P})$ factors. Generally, ecological rehabilitation can be an urgent and essential measure to solve the widespread land degradation problems. Therefore, even if area closure can be an effective method for rehabilitating degraded hillsides incorporating SWC measures could be possible options to speed up the rehabilitation period.

\section{Recommendation}

Based on the major findings; the following recommendations are suggested. The interference of local people and animal grazing in open grazing land should be protected to assist the vegetation rehabilitation and control soil erosion. Since the open grazing area has high accelerated erosion, to tackle this problem, there must be need area closure with the construction of SWC practices and afforestation activities. Even though rehabilitation of degraded areas depends on seed sources and management practices, SWC measures and enrichment planting should be incorporated into the closure area to reduce soil losses and improve the density, diversity, and regeneration of woody species. Concerned governmental and NGOs (especially, Lake Hawassa stakeholders) should give due attention to rehabilitate the whole hillside areas of the catchment since the area is at the upper catchment of Lake Hawassa. Further research works should focus on more understand the interactive relationships among landscape positions, soil properties, management interventions, land uses and its history since vegetation and soil attributes depend on those factors. Finally, study shall be conducted to investigate the underlying factors causing high soil erosion and assess the status of herbaceous plants species diversity and extent.

\section{Acknowledgements}

I would like to thank Mendel University in Brno Project in Ethiopia and Ministry of education for their financial support to the successful completion of this thesis work. My deepest gratitude also goes to Wondo Genet College of forestry and natural resources Soil Laboratory staffs in general and $\mathrm{Mr}$. Tizazu in particular for their timely analysis of soil samples.

\section{References}

[1] Evison, W. \& Knight, C. 2010. Biodiversity and business risk: A Global Risks Network briefing. In World Economic Forum (WEF), Geneva, Switzerland.

[2] Vlek, P. L., Le, Q. B. and Lulseged Tamene. 2008. Land decline in land-rich Africa. Science Council, Consultative Group on International Agricultural Research, London, Montpellier, 12: 596-598.

[3] Abate Shiferaw. 2011. Estimating soil loss rates for soil conservation planning in the Borena Woreda of South Wollo Highlands, Ethiopia. Journal of Sustainable Development in Africa, 13 (3): 87-106.

[4] Descheemaeker, K., Nyssen, J., Poesen, J., Raes, D., Mitiku Haile, Muys, B. and Deckers, S. 2006. Runoff on slopes with restoring vegetation: a case study from the Tigray highlands, Ethiopia. Journal of hydrology, 331 (1-2): 219-241. 
[5] Hurni, H., Kebede Tato, and Gete Zeleke. 2005. The implications of changes in population, land use, and land management for surface runoff in the upper Nile basin area of Ethiopia. Mountain Research and Development, 25 (2): 147154.

[6] Akalu Teshome, Rolker, D. and de Graaff, J. 2013. Financial viability of soil and water conservation technologies in northwestern Ethiopian highlands. Applied Geography, 37: 139-149.

[7] Daniel Danano. 2002. Soil and water conservation techniques and strategies for food security and poverty alleviation. In 12th ISCO Conference Beijing. pp. 358-365.

[8] Lemma Tiki, Menfes Tadesse and Fantaw Yimer, F. 2015. Effects of integrating different soil and water conservation measures into hillside area closure on selected soil properties in Hawassa Zuria District, Ethiopia. Journal of Soil Science and Environmental Management, 6 (10): 268-274.

[9] Kebede Wolka, Habitamu Tadesse, Efrem Garedew, and Fantaw Yimer. 2015. Soil erosion risk assessment in the Chaleleka wetland watershed, Central Rift Valley of Ethiopia. Environmental Systems Research, 4 (1): 5.

[10] Binyam Alemu, and Desale Kidane. 2014. The implication of integrated watershed management for rehabilitation of degraded lands: case study of Ethiopian highlands. Journal of Agriculture and Biodiversity Research, 3 (6); 78-90.

[11] Halcrow, G. 2010. Rift valley lakes basin integrated resources development plan study project. Lake Hawassa sub-basin integrated watershed management feasibility study. Main report, 1 .

[12] Menorgiet Zelalem. 2016. Comparative evaluation of community mobilization approaches on soil and water conservation measures for degraded land rehabilitation in Hawassa zuria Woreda, Sidama zone, Ethiopia. MSc. Thesis, Hawassa University, Hawassa. Pp 95.

[13] Gessesse Dessie and Johan, K. 2007. Pattern and Magnitude of Deforestation in the South Central Rift Valley Region of Ethiopia. Mountain Research and Development 27: 162168.

[14] Mendel University Project in Ethiopia (MUP). 2016. Degraded land rehabilitation as a base for sustainable management of natural resources, in HawassaZuryaWereda, SNNPR, Ethiopia. Report, Hawassa, Ethiopia. Pp 60.

[15] Walkley, A. and Black. CA. 1934. An examination of different methods for determining soil organic matter and the proposed modification of the chromic acid titration method. J Soil Sci 37: $29-38$.

[16] Tan, K. H. 2005. Soil sampling, preparation, and analysis. 2nd edition. CRC press.

[17] Hurni, H. 1985. Erosion-productivity-conservation systems in Ethiopia. Proceedings of the 4th International Conference on Soil Conservation, Maracay Venezuela. Pp. 654-674.

[18] Wischmeier, W. H. and Smith, D. D. 1978. Predicting rainfall erosion losses-a guide to conservation planning. Predicting rainfall erosion losses-a guide to conservation planning. USDA Agriculture Research Service Handbook, pp 58.

[19] Nearing, M. A. 2011. Handbook of Erosion Modelling. WileyBlackwell.
[20] Nyssen, J., Poesen, J., Descheemaeker, K., Nigussie Haregeweyn, Mitiku Haile, Moeyersons, J., Frankl, A., Govers, G., Munro, N. and Deckers, J. 2008. Effects of region-wide soil and water conservation in semi-arid areas: the case of northern Ethiopia. Zeitschrift für Geomorphologie, 52 (3): 291-315.

[21] Wolde Mekuria and Mastewal Yami. 2013. Changes in woody species composition following establishing exclosures on grazing lands in the lowlands of Northern Ethiopia. African Journal of Environmental Science and Technology, 7 (1): 3040.

[22] Shimeles Damene. 2012. Effectiveness of soil and water conservation measures for land restoration in the Wello area, northern Ethiopian highlands.

[23] Lemma Tiki and Menfes Tadesse. 2015. Effects of integrating different soil and water conservation into hillside area closure on woody species composition and structure in Hawassa Zuria District, Ethiopia. Journal of Agricultural Research, 4 (4): 40 49.

[24] Sokol, Z. and Bližňák, V. 2009. Areal distribution and precipitation-altitude relationship of heavy short-term precipitation in the Czech Republic in the warm part of the year. Atmospheric Research, 94 (4): 652-662.

[25] Renard, K. G., Foster, G. R., Weesies, G. A., McCool, D. K. and Yoder, D. C. 1997. Predicting soil erosion by water: a guide to conservation planning with the Revised Universal Soil Loss Equation (RUSLE). Washington, DC: United States Department of Agriculture, 703: 1-384.

[26] Fantaw Yimer, Getachew Alemu and Abdu Abdelkadir, A. 2015. Soil property variations in relation to exclosure and open grazing land use types in the Central Rift Valley area of Ethiopia. Environmental Systems Research, 4 (1): 17.

[27] Abebe, T., Hunde, D. and Kissi, E. 2014. Area Exclosure as a Strategy to Restore Soil Fertility Status in Degraded Land in Southern Ethiopia. J. Biol. Chem. Research, 31: 482-494.

[28] Tenge, A. J., J. de Graaff and J. P. Hella, 2005. Financial efficiency of major soil and water conservation measures in West Usambara highlands, Tanzania. Applied Geogr. 25: 348366.

[29] Teshome, A., Rolker, D. and de Graaff, J. 2013. Financial viability of soil and water conservation technologies in northwestern Ethiopian highlands. Applied Geography, 37: 139-149.

[30] Wolde Mekuria, Veldkamp, E., Mitiku Haile, Kindeya Gebrehiwot, Muys, B. and Nyssen, J. 2009. Effectiveness of exclosures to control soil erosion and local communities perception on soil erosion. African Journal of Agricultural Research, 4 (4): 365-377.

[31] Kidane Giday, Getachew Eshete, Barklund, P., Aertsen, W. and Muys, B. 2013. Wood biomass functions for Acacia abyssinica trees and shrubs and implications for provision of ecosystem services in a community managed exclosure in Tigray, Ethiopia. Journal of arid environments, 94: 80-86.

[32] Zenebe Adimassu, Langan, S., Johnston, R., Wolde Mekuria. and Tilahun Amede. 2017. Impacts of soil and water conservation practices on crop yield, run-off, soil loss and nutrient loss in Ethiopia: review and synthesis. Environmental management, 59 (1): 87-101. 